\title{
FACTORS INFLUENCING THE INTERNATIONALIZATION PROCESS OF BRAZILIAN BORN GLOBAL COMPANIES
}

\author{
Izabel Regina de Souza ${ }^{*}{ }^{\square}$, Miguelangelo Gianezini 2 (iD \\ ${ }^{* 1} \mathrm{PhD}$ candidate in Socioeconomic Development, UNESC University, Brazil \\ $2 \mathrm{PhD}$. Professor at the Postgraduate Program in Socio-Economic Development, UNESC University, \\ Brazil
}

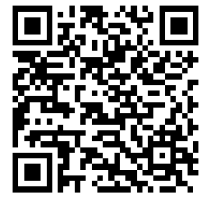

DOI: https://doi.org/10.29121/granthaalayah.v8.i12.2020.2694

Article Type: Research Article

Article Citation: Izabel Regina de Souza, and Miguelangelo Gianezini. (2020). FACTORS INFLUENCING THE INTERNATIONALIZATION PROCESS OF BRAZILIAN BORN GLOBAL COMPANIES. International Journal of Research -

GRANTHAALAYAH, 8(12), 130-140. https://doi.org/10.29121/granthaa layah.v8.i12.2020.2694

Received Date: 04 December 2020

Accepted Date: 31 December 2020

Keywords:

International Companies

Born Global

Brazil

Strategy

Emerging Markets

\section{ABSTRACT}

This study aimed to identify factors that influence the internationalization of Brazilian born global companies (BGs). The studies on the theme of internationalization have been developed in a specific area and have continuously refined themselves as a theoretical field of high relevance and prominence. These researches seek to follow the speed and changes of international business, especially the studies that focus on the phenomenon of accelerated internationalization or as called, Born Global. A search was carried out - in the annals of events (EnAnpad and Semead), Brazilian international business journals, and at Google ScholarTM - to identify empirical studies on the theme "internationalization of Brazilian born global companies." The results found point to a diversity of factors that can influence BG companies' internationalization process, such as networks, geographic location, product differentiation, intensive use of technologies, and product innovation. However, the most relevant issue (and that demands new specific studies) is the "profile of the entrepreneur" as a factor of significant influence in the internationalization of the Brazilian BGs.

\section{INTRODUCTION}

The last three decades (1990-2000-2020) have presented a concentration of research in international ventures, especially in early internationalized companies, called Born Globals (BGs), such as the studies of Oviatt and McDougall (1994), Madsen and Servais (1997), Oviatt and McDougall (1997), Knight and Cavusgil (2004) and Knight (2016). BGs are displayed as companies that establish activities abroad since their foundation or a few years after their creation. These companies usually assume business in the international market simultaneously with the establishment of business in the domestic one, and many times, even without any experience or with little operation in the domestic market itself. This placement is based on the works of the authors as Kim (2009), Rialp et al. (2005), Cavusgil and Knight (2010), and Knight (2016).

Since the pioneering work of Oviatt and McDougall (1994) on BG companies' phenomenon, much has been discussed in academia on this topic. However, the literature already produced still presents different denominations and variations of the concept of accelerated internationalization (RIALP et al., 2005). Internationalization in the early

(c) 2020 The Author(s). This is an open access article distributed under the terms of the Creative Commons Attribution License, which permits unrestricted use, distribution, and reproduction in any medium, provided the original author and source are credited. 
years of the constitution of companies can be called international new ventures (Oviatt and McDougall, 1994; 1995), global start-ups (Madsen and Servais, 1997; Oviatt and McDougall, 1995), global high-tech firms (Roberts and Senturia, 1996), among many other denominations, included born globals (Knight and Cavusgil, 1996). For this study, we adopted the term born globals (BGs) because it is the most general term in national (Brazilian) and international literature.

The nomenclature given to this phenomenon does not mischaracterize a change in behavior observed in internationalized companies in recent years due to globalization. In fact, what is observed is that studies on this subject have presented a diversification of factors that can lead to the internationalization of BGs.

Several authors sought to investigate factors that lead new companies to follow the accelerated path in the internationalization process instead of following the traditional one, that is, the gradual mode. The model of gradual internationalization best known in the literature is based on incremental steps presented by (Vernon 1966; 1971; 1979; Johanson and Vahlne 1977, 1990), where "companies internationalize as they acquire experiences with the foreign market".

The BGs skip the steps described in the traditional internationalization model described by Johanson and Vahlne $(1975 ; 1977)$ and present distinct factors that lead the new companies to internationalize since the beginning of operations with foreign markets, and often without any previous experience on a particular market. One feature observed in studies on BGs is that these companies are typically small and medium-sized and have limited tangible resources (Cavusgil and Knight, 2009; Freeman, Edwards, Schroder, 2006). Nevertheless, on the other hand, they are endowed with distinct intangible resources and capacities (Knight and Cavusgil, 2004; Jantunen et al., 2008; Rialp et al., 2005), which enable them to be more skilled in allocating their resources (Cavusgil and Knight, 2015).

Regarding this context, this study seeks to identify the factors that actually influence the internationalization of Brazilian BGs companies. It is essential to highlight that this research is part of a more extensive study on born global companies, which will seek to understand the factors that influence the internationalization of BG companies from emerging countries. However, to move forward, it is necessary to know the influencing factors in the process of internationalization of this kind of company in the country of origin.

\section{INTERNATIONALIZATION: CONCEPTS AND MODELS}

Studies on internationalization have been relevant to understand the movements that organizations make to internationalize facing the fast global market changes. Seeking to keep up with the pace of changes in global business, the internationalization theory has been continuously developing since the 1970s. This theory has established itself as a theoretical body of great relevance and prominence in studies on companies' internationalization. On this theoretical body, it is possible to highlight some studies that contributed to the explanation of the internationalization process, such as the Uppsala model (behavioral model), which has its aspect in the behavioral field of organizations (Johanson and Wiedersheim-Paul, 1975; Johanson and Vahlne, 1977; 1990), and the Economic model, where the decision of internationalization takes place through economic rationality. The main theories are the Market Power (Hymer, 1960), the theory of internalization (Buckley and Casson, 1976), the theory of Transaction Cost (Anderson and Gatignon, 1986; Hennart, 2010; Williamson, 1975), and the Eclectic Paradigm (Dunning, 1977; 1988).

The behavioral model initially described by Johanson and Vahlne (1977; 1990), is also known as the Uppsala model, and establishes that the company's internationalization process involves gradually obtaining market knowledge. Thus, as the company engages and learns from the foreign market dynamics, the more it compromises its resources and develops in this market. The experience that the company acquires with the foreign market enables it to develop new goals and define more significant investments, consequently reducing the company's perception of risks in non-domestic countries. Moreover, the most recognized works of the theory of internationalization are the works of the Uppsala School (Johanson and Vahlne, 1977; 1990), the Cavusgil Innovation Model (1980), in addition to subsequent developments such as Networks, International Entrepreneurship and BGs (Knight and Cavusgil, 2004).

The studies of networks are based on the premise that companies are organized in networks and that in the international sphere, companies establish relationships with other foreign companies (Johanson and Mattson, 1988). Following the cited authors' idea, the company internationalizes through another company that is part of its 
network of relationships. When it comes to small and medium-sized enterprises, networks' perspective provides companies with difficulties such as lack of access to economies of scale, lack of knowledge, lack of resources, or limited resources, and risk aversion. This approach's paramount collaboration advocates that companies use resources available in a network to achieve their strategic objectives (Dib, 2008).

The study of international entrepreneurship is based on two theoretical perspectives: Resource Based-View and Networks. The first helps to identify critical resources for a new venture's success, while the second demonstrates the vital role of cooperative actions and relationships. For Oviatt and McDougall (1994), new international ventures represent a unique challenge to existing theories, and none of them can fully explain the reasons why this type of company exists. Johanson and Vahlne's work (1990) presents some exceptions for the acceleration of the internationalization process. However, the authors pointed out these exceptions do not justify the existence of new international ventures since they are in volatile markets, have few resources available, and do not have any kind of international experience. For Wennberg and Holmquist (2008), the entrepreneur and the company's characteristics are what determines the behavior in decision-making, including when the decision is for internationalization. This behavior is influenced by the knowledge and relationship networks that the entrepreneur has. The more knowledge in the foreign market and the greater the network of relationships that the entrepreneur has, the more possible can be the process of internationalization of the company as well as the speed of internationalization.

The influence of knowledge acquisition and relationship networks on the internationalization process's speed is pointed out by Sharma and Blomstermo (2003) as born globals. For the same authors, BGs already have international market knowledge before entering a foreign market for the first time, either through the entrepreneur's experience or by the contacts that the company or the entrepreneur has in other markets. The authors also point out that BGs would have a competitive advantage over so-called "regular companies" since their relationships tend to be weak and scattered since they are small, young, and knowledge-intensive companies. Thus, when it comes to the internationalization of BG companies, both stage models and theories related to the perspective of networks or entrepreneurship help in their understanding of the internationalization process (Gabrielsson et al., 2008; Dib et al., 2010).

The process of internationalization can still be understood from the perspective of the Economic Model. The internationalization model "under" economic perspective had its premises in Vernon's studies (1966; 1979) that addressed the potential of the consumer market to explain the process of internationalization. This model emphasized the product innovation cycle, the effects of economies of scale, and the roles of ignorance and uncertainty in marketing patterns. Later another model, the Eclectic Paradigm - also known as the ownership, location, internalization (OLI) model or OLI framework - uses the principles of transaction cost theory for internationalization decisions (Dunning, 1980; 1988; 2000). The decision of a company to operate abroad depends on the analysis between the costs of coordinating the activity within the company's structure. From there, a subsidiary is created abroad - and the transaction costs of the operation by the market, either through export or licensing of the brand or franchises.

Internationalization has been evolving to keep up with the changes that globalization imposes on markets. Not all companies that are internationalized go through processes as described in the models highlighted above. Internationalization strategies do not follow standards but follow the company's ability to innovate and seek new ways to internationalize. This is the case of the phenomenon of so-called born global companies.

\section{BORN GLOBALS: CONCEPTS AND CHARACTERISTICS}

The phenomenon of the internationalization of companies in a premature and fast way caught researchers' attention in the 1990s. Thus, in the international literature, companies that had the process of accelerated internationalization obtained the name of BGs. These companies were born global or were born to operate in foreign markets. The emergence of these companies results from social, technological, and environmental changes experienced since the 1990s. BGs can be considered a more agile and effective evolution of the internationalization process (Madsen and Servais, 1997).

The acceleration of internationalization of companies is related to the changes that the business environment has been going through in recent decades. An example is the increasing degree of demand of consumers who have started to demand specialized and personalized products, creating niche markets and opening opportunities for smaller companies that, with the technologies present, can compete for costs and quality. The communications 
revolution also allowed companies to manage and do business anywhere in the world. These factors have changed the life cycle of the products, making them shorter and smaller. All these required companies to be more agile and adaptable to respond at the same speed (Rennie, 1993; Oviatt and McDougall, 1994; Madsen and Servais, 1997).

Unlike Uppsala school companies' internationalization model, BG companies' internationalization does not take place slowly and progressively. However, there is still no consensus for a concept that clearly describes the model of BGs internationalization (Hashai and Almor, 2004). Studies on this theme still differ about the age at which the international activity begins, the representativeness of the export in total revenue, or the number of countries to which it is exported, among other factors (Dib et al., 2010).

The studies of Welch and Wiederheim (1980) was one of the first works to address the BG phenomenon and showed a significant increase in accelerated export operations after World War II. However, the most recognized works on the subject appeared in the mid-1990s (Knight and Cavusgil, 1996; Madsen and Servais, 1997; Oviatt and McDougall, 1994; Rennie, 1993). Among the authors cited, Knight and Cavusgil's studies are the ones that appear most frequently in research on accelerated internationalization, or BGs. Some concepts of BGs are described in Ribeiro (2012), the pioneer quantitative study on this type of company in Brazil (see Table 1).

Table 1: Main definitions of born global companies

\begin{tabular}{|c|c|}
\hline Authors & Main Definitions \\
\hline $\begin{array}{c}\text { Oviatt e } \\
\text { McDougall } \\
(1994)\end{array}$ & $\begin{array}{c}\text { Business organizations that from the conception or beginning of their activities seek business } \\
\text { in the foreign market, seek to generate significant competitive advantage from the use of their } \\
\text { resources and the sale of their products in different countries }\end{array}$ \\
\hline $\begin{array}{c}\text { Knight e } \\
\text { Cavusgil } \\
(1996)\end{array}$ & $\begin{array}{c}\text { Vision and strategy based on aspirations of an international or global position } \\
\text { Knight e } \\
\begin{array}{c}\text { Cavusgil } \\
(2004)\end{array}\end{array}$ \\
\hline $\begin{array}{c}\text { Dib } \\
(2008)\end{array}$ & $\begin{array}{c}\text { Business organizations that, since their training, seek superior performances in international } \\
\text { business from the application of knowledge-based resources to sell products in multiple } \\
\text { countries }\end{array}$ \\
\hline
\end{tabular}

Source: Adapted from Ribeiro (2012)

As already mentioned, the concept of born globals still generates disparities among scholars. Regarding these disparities involving the BGs phenomenon, Dib (2008) gathered the characteristics highlighted by the leading authors (Table 2).

Table 2: Main Characteristics of the born globals (BGs) internationalization process

\begin{tabular}{|c|c|c|}
\hline \multicolumn{2}{|r|}{ Born Global Features } & Main Authors \\
\hline $\begin{array}{l}\text { Start of International } \\
\text { Activities }\end{array}$ & $\begin{array}{l}\text { "Soon after the foundation", being the "fashion" } \\
\text { of the literature three years, although there are } \\
\text { indications of up to eight years or more. }\end{array}$ & $\begin{array}{l}\text { Knight e Cavusgil, 1996; } \\
\text { Zucchella, 2002, Gabrielsson } \\
\text { et al., 2004; Knight, Madsen } \\
\text { and Serverais, } 2004 .\end{array}$ \\
\hline $\begin{array}{l}\text { The relevance of } \\
\text { international activities }\end{array}$ & $\begin{array}{l}\text { A fraction of the total sales should come from } \\
\text { international activities, being the "fashion" of the } \\
\text { literature at least } 25 \% \text {, with variations for less or } \\
\text { more. }\end{array}$ & $\begin{array}{l}\text { Knight, 1997; Knight and } \\
\text { Cavusgil, 2004; Knight, } \\
\text { Madsen and Servais, } 2004 .\end{array}$ \\
\hline Input mode & $\begin{array}{l}\text { Flexible, typically more active as agent usage } \\
\text { (although unsolicited requests may also exist) }\end{array}$ & $\begin{array}{l}\text { Bell, 1995; Gabrielsson et al, } \\
\text { 2008; Knight and Cavusgil, } \\
2004 .\end{array}$ \\
\hline $\begin{array}{l}\text { Scope of international } \\
\text { activities }\end{array}$ & $\begin{array}{l}\text { The greater the number of coordinated value } \\
\text { chain activities between countries, the more BG } \\
\text { the company would be. }\end{array}$ & $\begin{array}{l}\text { Oviatt and McDougall, 1994; } \\
\text { Autio et al., 2000. }\end{array}$ \\
\hline
\end{tabular}


Factors Influencing the Internationalization Process of Brazilian Born Global Companies

\begin{tabular}{|c|c|c|}
\hline Geographic Coverage & $\begin{array}{c}\text { The greater the geographical scope concerning } \\
\text { the number of countries, the more BG the } \\
\text { company would be. }\end{array}$ & $\begin{array}{c}\text { Oviatt and McDougall, 1994; } \\
\text { Gabrielsson, 2008. }\end{array}$ \\
\hline $\begin{array}{c}\text { Motivations for } \\
\text { internationalization }\end{array}$ & $\begin{array}{c}\text { BG would have motivations more linked to a clear } \\
\text { and proactive strategy, seeking to be } \\
\text { international since the foundation and take a } \\
\text { prominent position in global niche markets. }\end{array}$ & $\begin{array}{c}\text { Bell, 1995; Chetty and } \\
\text { Campbell-Hunt, 2004; Rocha, } \\
2004\end{array}$ \\
\hline $\begin{array}{c}\text { Geographical dispersion of } \\
\text { customers in the domestic } \\
\text { market }\end{array}$ & $\begin{array}{c}\text { Specifically, in the Brazilian case, companies with } \\
\text { national operations would be more likely to } \\
\text { internationalize than companies that have not yet } \\
\text { operated in other regions of the country. }\end{array}$ & $\begin{array}{c}\text { Study of Brazilian cases in } \\
\text { Rocha, 2004; and Rocha et al., } \\
\text { 2007. }\end{array}$ \\
\hline
\end{tabular}

Source: Adapted from Dib (2008)

Different studies used different definitions through choices between characteristics such as the beginning of international activities, the relevance of activities, mode of entry, geographical scope, and foundation year. As this work focuses on Brazilian born global companies, the concept of BGs presented by Dib (2008) was chosen. Besides, a search was carried out - in the annals of events (EnAnpad and Semead), Brazilian international business journals, and at Google Scholar ${ }^{\mathrm{TM}}$ - to identify empirical studies on the theme "internationalization of Brazilian born global companies."

\section{RESULTS AND DISCUSSIONS}

The emergence of BG companies has received increasing attention in research on internationalization. In addition to the contrast to the traditional theory of internationalization, BG companies present a condition of innovative companies, based on new inducing elements present in other theories such as relationship networks, distribution channels, entrepreneurship, organizational innovation, and the internet or the combination of them (Sharma and Blomstermo, 2003; Gabrielsson and Kirpalani, 2004).

Even so, it is perceived that there is a vast path to be followed so that we can better understand what factors actually influence the process of internationalization of BGs, especially in empirical studies of Brazilian companies. Considering this reality and given the dispersion found in the international literature, this study aims to describe the factors highlighted in Brazilian articles, which influence the internationalization of Brazilian BGs.

Before presenting results of some empirical studies in Brazilian companies, it is also worth to regard at the explicit factors in some studies since the 90s - to explain the speed of the internationalization process - such as: Rennie (1993), highlighted the flexible and rapidly responsive organization to justify rapid internationalization; Zuchella (2002) considered the existence of singular assets; Chetty and Campbell-Hunt (2004), the niche strategy is an essential factor; Evangelista (2005), points to product differentiation; and Loane (2006) the intensive use of information technology.

The existence of factors linked to relationship networks influences the speed of the internationalization process, according to the research: intensive use of partnerships with other companies (Gabrielsson, 2005); integration to international business networks (Johanson and Mattson, 1988); use of personal networks as facilitators in internationalization (Loane, 2006) and cluster insertion (Zuchella, 2002).

It is also possible to find in the literature characteristics of the entrepreneur that influence the speed of the internationalization of a company, guidance and international experience (Knight, Madsen and Servais, 2004); greater risk tolerance (Madsen and Servais, 1997) and unique technical/scientific knowledge (Chetty and CampbellHunt, 2004).

In Brazil, as in many emerging countries, studies on the phenomenon of BGs have not yet been limited. In a research in databases of scientific congresses, journals, master's theses, and doctorates of Brazilian universities, few studies with empirical research on the subject were found. Some studies point to a clarification of the theories of internationalization as is the case of the work of Dib and Carneiro (2006) that sought to compare the theories: Theory of Market Power, Theory of Internalization, Eclectic Paradigm, Uppsala Model, Perspective of Networks and International Entrepreneurship - and their contribution to answering five basic questions: why, what, when, where and how companies internationalize (their activities). Furthermore, in the end, they suggested that a new general or 
specific theory would be necessary to deal with the increasing complexity and variability of the processes of internationalization of companies.

Carvalho and Paes (2006) evaluated the main drivers associated with BG companies' internationalization process in Brazil. The authors identified the non-geographical specificity of the internationalization pattern of global born companies. Besides, they confirm the importance of globalization degree of the sector to induce the rapid involvement of organizations with business activities abroad.

The work of Dib and Rocha (2008) focused on the master line of research on BGs, by developing a survey among companies in the Brazilian software industry, comparing the characteristics of companies internationalized by the gradual process, predicted in behavioral theories, with the process of early and accelerated internationalization that characterizes the BGs. The study started with a comprehensive literature review. A conceptual model was constructed consisting of four "blocks of factors": related to company characteristics, relationships with networks, characteristics of the entrepreneur, and the type of internationalization process studied. An internet survey was conducted, obtaining a final sample of 79 software developer companies. The results allowed identifying some factors in the conceptual model that would differentiate companies from early internationalization from those of gradual internationalization.

In 2009, Ribeiro and Pimentel analyzed Brazilian cases of BG companies. The study focused on the relationship between the entrepreneur's profile and a certain region and the success of the enterprise. The research revealed two enterprises from Campinas city (São Paulo state) that were examples of successful BGs in Brazil. For the authors, the main factors that contribute to this success are the entrepreneur behavior; the location in a "technological pole" region, close to an innovative public university; and the support of the government through financing. These characteristics raised show compliance with the international theoretical framework on the subject.

Silva, Chauvel, and Bertrand (2010) conducted a case study in a small Brazilian technology company internationalizing to Australia. The company can be characterized as a BG. In accordance with the literature, it was evidenced that the entrepreneurial profile and the network are preponderant factors in this company's internationalization process. Moreover, it was observed that the network had the main contribution to reduce the psychic distance and, also, that its internationalization led to the acquisition of new resources relevant to its functioning.

Four case studies with companies based in the city of Rio de Janeiro - that did the first international business until the fifth year of its foundation - were carried out by Silva and Dib (2011). The authors describe technological innovations in communication, transportation, and production, the shortening of distances, changes in consumer preferences, and market specialization as factors of change that influenced the four companies' rapid internationalization process.

Also, on the studies of Silva and Dib (2011) and based on the literature, the authors look at the existing theoretical models and point out characteristics of BG companies such as: i) customer orientation; ii) intensive use of information technology; iii) existence of natural assets; iv) product differentiation and niche strategy; v) contributions of the theories of international entrepreneurship that indicate that an entrepreneur with international orientation and experience, greater tolerance to risk and with unique technical and scientific knowledge can be fundamental in accelerating the internationalization process; and finally vi) subsidies from the Perspective of Networks, which points out that companies with rapid internationalization may be linked to international business networks, clusters or use personal contact networks to accelerate their internationalization. The result of this research pointed out that two of the four companies studied were effectively international since their foundation. In contrast, the others, even with the internationalization process and can also be classified as BGs, were less fast to reach the international market. From what is observed, the greater speed seems to originate in one of the most notable international experience cases and the network of contacts of the founder and another case of an intention of internationalization from the beginning.

In his doctoral thesis, Ribeiro (2012) analyzed the relationship of factors of the company's external environment in the country of origin, organizational factors, and factors of the entrepreneur by which some Technology-Based Companies (TBCs) are internationalized in an accelerated manner since its foundation or a few years after its foundation. The analysis was performed on 54 employs of TBCs, and the results showed that the companies' external factors influence more than the company's internal factors. Thus, the location, partnerships, government policies, and integration into the value chain significantly explain the internationalization of TBCs. Integration into global production chains is the factor that best discriminates the internationalization of born global TBCs. Concerning the 
entrepreneur's factors, the international managerial skills of the entrepreneur also appear as important in the accelerated internationalization of TBCs.

Souza and Lima (2016) reviewed the theories of internationalization. They suggested several initiatives for research on the theme of internationalization of BG, such as identifying the real factors that lead to BG companies internationalizing.

The entrepreneurial profile was also the focus of the study of Picchiai and Zorzetti (2018). This work's objective was to analyze the profile of entrepreneurs from companies that have become internationalized in an accelerated manner. For the research, a convenience sample was used composed of six companies that answered a questionnaire and a collection of information about the companies selected through the company's website, and the application of a semi-structured questionnaire to the partners or directors of the companies. The results pointed out the importance of the entrepreneur's previous experience in multinational companies, his influence as an investor man with technical or scientific knowledge, and his international orientation as an essential factor in BG companies.

Regarding all these researches, we made a compilation of factors found in the analyzed studies (Table 3). Since to understand the phenomenon of accelerated internationalization in Brazil, it was necessary to understand how this also occurs in other countries, and it is possible to describe these factors of Brazilian and foreign companies according to studies presented above.

Table 3: Factors influencing the born globals internationalization process

\begin{tabular}{|c|c|c|c|}
\hline \multicolumn{2}{|c|}{$\begin{array}{l}\text { Factors that somehow influence the } \\
\text { internationalization of BGs around the world }\end{array}$} & \multicolumn{2}{|r|}{$\begin{array}{l}\text { Factors that influence in some way the } \\
\text { internationalization of BGs in Brazil }\end{array}$} \\
\hline $\begin{array}{l}\text { Rennie } \\
\text { (1993) }\end{array}$ & $\begin{array}{l}\text { A flexible and responsive } \\
\text { organization }\end{array}$ & $\begin{array}{l}\text { Dib and } \\
\text { Carneiro } \\
(2006)\end{array}$ & $\begin{array}{c}\text { Analysis and comparison of traditional theories. } \\
\text { Traditional theories do not explain the } \\
\text { phenomenon of BGs. }\end{array}$ \\
\hline $\begin{array}{l}\text { Zuchella } \\
\text { (2002) }\end{array}$ & Existence of singular assets & $\begin{array}{l}\text { Carvalho } \\
\text { and Paes } \\
(2006)\end{array}$ & $\begin{array}{l}\text { Non-geographical specificity of the } \\
\text { internationalization standard. Importance of } \\
\text { the degree of globalization of the country. }\end{array}$ \\
\hline $\begin{array}{c}\text { Chetty and } \\
\text { Campbell-Hunt } \\
(2004) \\
\end{array}$ & Niche strategy & $\begin{array}{l}\text { Dib and } \\
\text { Rocha } \\
(2008) \\
\end{array}$ & $\begin{array}{c}\text { To relationships with networks, characteristics } \\
\text { of the entrepreneur, and the type of } \\
\text { internationalization process }\end{array}$ \\
\hline $\begin{array}{c}\text { Evangelista } \\
\text { (2005) }\end{array}$ & Product differentiation & $\begin{array}{l}\text { Ribeiro and } \\
\text { Pimentel } \\
\text { (2009) }\end{array}$ & $\begin{array}{c}\text { Profile of the entrepreneur; location } \\
\text { (technological hub); government support. }\end{array}$ \\
\hline- & - & $\begin{array}{c}\text { Silva, } \\
\text { Chauvel e } \\
\text { Bertrand } \\
(2010)\end{array}$ & Profile of the entrepreneur; network \\
\hline $\begin{array}{l}\text { Loane } \\
\text { (2006) }\end{array}$ & $\begin{array}{l}\text { Intensive use of information } \\
\text { technology }\end{array}$ & $\begin{array}{l}\text { Silva and Dib } \\
\qquad(2011)\end{array}$ & $\begin{array}{l}\text { technological innovations in communication; } \\
\text { transport and production; shortening distances; } \\
\text { changes in consumer preferences; and } \\
\text { specialization of markets }\end{array}$ \\
\hline $\begin{array}{l}\text { Gabrielss } \\
\text { on (2008) }\end{array}$ & $\begin{array}{l}\text { Intensive use of } \\
\text { partnerships with other } \\
\text { companies - Networks }\end{array}$ & $\begin{array}{l}\text { Ribeiro } \\
(2012)\end{array}$ & $\begin{array}{c}\text { External factors: the location, partnerships, } \\
\text { government policies, and integration into the } \\
\text { value chain significantly explain the process of } \\
\text { internationalization of TBCs } \\
\text { Internal factors: international managerial skills } \\
\text { of the entrepreneur }\end{array}$ \\
\hline $\begin{array}{l}\text { Johanson and } \\
\text { Mattson } \\
\text { (1988) }\end{array}$ & $\begin{array}{l}\text { Integration to international } \\
\text { business networks }\end{array}$ & $\begin{array}{c}\text { Souza and } \\
\text { Lima (2016) }\end{array}$ & $\begin{array}{c}\text { Review of theories and suggestion of } \\
\text { identification of the real factors of BGs } \\
\text { internationalization. }\end{array}$ \\
\hline $\begin{array}{l}\text { Loane } \\
(2006)\end{array}$ & & & $\begin{array}{l}\text { The entrepreneur; influence as an investor man } \\
\text { with technical or scientific knowledge and his }\end{array}$ \\
\hline
\end{tabular}


Izabel Regina de Souza, and Miguelangelo Gianezini

\begin{tabular}{|c|c|c|c|}
\hline & $\begin{array}{l}\text { Use of personal networks as } \\
\text { facilitators in } \\
\text { internationalization }\end{array}$ & $\begin{array}{l}\text { Picchiai and } \\
\text { Zorzetti } \\
\text { (2018) }\end{array}$ & $\begin{array}{l}\text { international orientation as an essential factor } \\
\text { in BG companies. }\end{array}$ \\
\hline $\begin{array}{l}\text { Zuchella } \\
(2002)\end{array}$ & Clustering & & \\
\hline $\begin{array}{c}\text { Knight, } \\
\text { Madsen, e } \\
\text { Servais (2004) }\end{array}$ & $\begin{array}{l}\text { Characteristics of the } \\
\text { entrepreneur }\end{array}$ & & - \\
\hline $\begin{array}{c}\text { Madsen and } \\
\text { Servais (1997) }\end{array}$ & Increased risk tolerance & & \\
\hline $\begin{array}{c}\text { Chetty and } \\
\text { Campbell-Hunt, } \\
(2004)\end{array}$ & $\begin{array}{l}\text { Scientific, technical } \\
\text { knowledge }\end{array}$ & & \\
\hline
\end{tabular}

In fact, many factors influence the process of early internationalization of companies. However, it is worth highlighting some convergent points found in the studies conducted in several emerging countries and the work carried out in Brazil. The issue of the entrepreneur/manager profile is a factor that draws attention, as well as the integration to networks the experience of the entrepreneur/manager in the international market and the use of information technologies. It can be said that the network contributes to the success of these companies so that it helps to identify, through partners, new market opportunities, and builds market knowledge.

In this context, the innovative, proactive, and accepting behavior of the executive in conjunction with an allied network, that is, a network helps to identify resources to explore the international market and achieve market and technological knowledge. Both are factors to enter the international market and leverage Born Global's development and performance in this market. Another point of significant prominence that converges with the literature is the entrepreneur's profiler, which according to Andersson (2000), explains that the entrepreneur's adequate performance is the condition for the internationalization of these companies in an accelerated way.

The differentiation of the product and the geographical location, despite appearing in the works of Ribeiro and Pimentel (2009) and Evangelista (2005), does not seem to be a very preponderant factor in the internationalization process of BG companies since it does not frequently appear in the influencing factors in the process of early internationalization. What leads us to think that participating in international relationship networks and having a bolder entrepreneurial profile are factors that really influence the internationalization process of Brazilian BGs.

\section{CONCLUSION}

In order to identify the factors that may explain the process of early internationalization of BG companies in Brazilian studies, it was possible to identify some relevant factors pointed out, such as the importance of the profile of the entrepreneur/manager in this process, participation in networks of relationships with the foreign market, as well as the experience of the entrepreneur with the international market.

As an emerging economy, Brazil still lacks technological development. For this reason, unlike in developed countries, the intensive use factor of information technology is not a factor that appears as relevant in the studies of Brazilian BG companies. What most often explains the process of internationalization of Brazilian BGs is the entrepreneurial profile. The entrepreneur can be conditioned since it motivates the company to enter the foreign market. Is a person willing to seize opportunities and face challenges, a decisive factor for the internationalization process's success and continuity of the internationalization process?

The work results also point to the importance of studying the role of the international entrepreneur more thoroughly to understand the difference between companies that have this entrepreneurial manager and those that do not have a manager with this profile. In addition to influencing the decision to go to foreign markets, the experience, network, and contacts of the entrepreneur in other markets point to opportunities and help considerably in overcoming difficulties. Although international opportunities are available to all, it is worth noting that only a few individuals can develop them. Thus, even if the knowledge of these opportunities reaches the entrepreneur through their contacts, only some of them will recognize and develop it. 
Factors Influencing the Internationalization Process of Brazilian Born Global Companies

\section{SOURCES OF FUNDING}

This research received no specific grant from any funding agency in the public, commercial, or not-for-profit sectors.

\section{CONFLICT OF INTEREST}

The author have declared that no competing interests exist.

\section{ACKNOWLEDGMENT}

To professors and colleagues from the course Advanced Topics in Socio-Economic Development. To the Research Group in Strategy, Competitiveness and Development (GEComD) and the Postgraduate Program in SocioEconomic Development of UNESC University, Brazil.

\section{REFERENCES}

[1] ANDERSON, E., GATIGNON, H. (1986). Modes of Foreign Entry: A Transaction Cost Analysis and Propositions. Journal of International Business Studies, 17, p. 1-26.

[2] AUTIO, E.; et al. (2000). Effects of age at entry, knowledge intensity, and imitability on international growth. The Academy of Management 43. p. 909-924.

[3] BELL, J. (1995). The Internationalization of Small Computer Software Firms. European Journal of Marketing, 29(8), p. 60-75.

[4] BUCKLEY, P. J., CASSON, M. (1976). The Future of the Multinational Enterprise. London: Palgrave Macmillan. $116 \mathrm{p}$.

[5] CAVUSGIL, S. T.; KNIGHT, G.; RIESENBERGER, J. R. (2010) Negócios internacionais: estratégia, gestão e novas realidades. São Paulo: Pearson Prentice Hall.

[6] CAVUSGIL, S. T.; KNIGHT (2009). Born Global Firms: A New International Enterprise. Business Expert Press, $125 p$.

[7] CAVUSGIL, S. (1980). On the internationalization process of firms. European Research, v. 8, p. 273-81.

[8] CARVALHO, S.; PAES, L.R.A. (2006). Drivers da Internacionalização de Born globals: Estudo de uma Empresa de Syndication. 30 Encontro Anpad. 23 a 27 de set. de 2006. Salvador.

[9] CHETTY, S., CAMPBELL-HUNT, C. (2004). A strategic approach to internationalization: a traditional vs. a bornglobal approach. Journal of International Marketing, 12(1), p.57-81.

[10] DIB, L. A. R. (2008). O processo de internacionalização de pequenas e médias empresas e o fenômeno born global: estudo do setor de software no Brasil. Tese de doutorado. Instituto COPPEAD de Administração, Universidade Federal do Rio de Janeiro.

[11] DIB, L. A.; ROCHA, A. (2008) Internacionalização Precoce versus Internacionalização Gradual: um Estudo sobre Born Globals na Indústria Brasileira de Software. 32 Encontro Anpad. 6 a 10 set. de 2008, Rio de Janeiro.

[12] DIB, L. A. da R.; CARNEIRO, J. (2006). Avaliação comparativa do escopo descritivo e explanatório dos principais modelos de internacionalização de empresas. In: 30 Encontro Anpad. 23 a 27 de set. de 2006. Salvador.

[13] DIB, L. A. da R. et al. (2007) A internacionalização acelerada de pequenos empreendimentos: reconciliando perspectivas concorrentes. In: VI Workshop em Internacionalização de empresas. Anais... v.1, Rio de Janeiro: Coppead/UFRJ.

[14] DIB, L. A., ROCHA, A., SILVA, J. (2010). The internationalization process of Brazilian software firms and the born global phenomenon: examining firm, network, and entrepreneur variables. Journal of International Entrepreneurship, 8, p.233-253.

[15] DUNNING, J. (1988). The Eclectic Paradigm of international production: a restatement and some possible extensions. Journal of International Business Studies, 19(1), p.1-31.

[16] DUNNING, J. H. (1988). The Eclectic Paradigm of International Production: A Restatement and some Possible Extensions. Journal of International Business Studies, 19, p. 1-32. 
Izabel Regina de Souza, and Miguelangelo Gianezini

[17] EVANGELISTA, F. (2005). Qualitative insights into the international new venture creation process. Journal of International Entrepreneurship, 3, p.179-198.

[18] GABRIELSON, M.; KIRPALANI, V. H. (2004). Born Globals: How to Reach New Business Space Rapidly. International Business Review, 13, p.555-571.

[19] GABRIELSSON, M., et al. (2008). Born Globals: propositions to help advance the theory. Intl Business Review, 17, p.385-401

[20] FREEMAN, S.; EDWARDS, R.; SCHRODER, B. (2006). How Smaller Born-Global Firms Use Networks and Alliances to Overcome Constraints to Rapid Internationalization. Journal of international marketing. V. 14, $\mathrm{n}$. 3, p.33-63

[21] HENNART, J.-F. (2010). Transaction Cost Theory and International Business. Journal of Retailing, 86(3), p.257269.

[22] HYMER, S. (1960). The international operations of national firms: a study of direct foreign investments. Cambridge, Mass: MIT Press.

[23] JANTUNEN, A. et al. (2008) Strategic orientations of born globals: Do they really matter? Journal of Word Business. v.43, 2, p.158-170.

[24] JOHANSON, J.; WIEDERSHEIM-PAUL, F. (1975). The Internationalization of the Firm: Four Swedish Cases. Journal of Management Studies, 22(4), p.305-322.

[25] JOHANSON, J.; VAHLNE, J. (1977). The Internationalization Process of the Firm - a model of knowledge development and increasing foreign market commitments. Journal of International Business Studies, 8/1: 2332.

[26] JOHANSON, J.; VAHLNE, J. (1990). The Mechanism of Internationalization. International Marketing Review. 7/4: p.11-24.

[27] JOHANSON, J., MATTSON, L. (1988). Internationalization in industrial systems: a network approach. In N. Hood; J. Vahlne (Eds.). Strategies in global competition. New York: Routledge.

[28] KNIGHT, G., MADSEN, T., SERVAIS, P. (2004). An inquiry into born-global firms in Europe and the USA. International Marketing Review, 21(6), 645-665.

[29] KNIGHT, G. A; CAVUSGIL, S. T. (2004). Innovation organizational capabilities, and the born global firm. Journal of International Business Studies, 35, p.124-152.

[30] KNIGHT, G. A; CAVUSGIL, S. T. (1996). The born global RM: A challenge to traditional internationalization theory. Advances In: International Marketing, v. 8, p.11-26.

[31] KNIGHT, G. (1997). Emerging Paradigm for International Marketing: The Born-Global Firm. Doctor of Philosophy, Department of Marketing and Supply Chain Management, Michigan State University, Michigan, EUA.

[32] KNIGHT, G. A; KIM, D. (2009). International business competence and the contemporary firm. Journal of International Business Studies, 40, p. 255-273.

[33] KNIGHT, G.; LIESCH, P. W. (2016) Internationalization: From incremental to born global. Journal of World Business, 51, p.93-102.

[34] LOANE, S. (2006). The role of the internet in the internationalization of small and medium sized companies. Journal of International Entrepreneurship, 3a, p.263-277.

[35] MADSEN, T.; SERVAIS, P. (1997). The internationalization of Born Globals: an evolutionary process? International Business Review, 6(6), 561-583.

[36] McDOUGALL, P. P., SHANE, S.; OVIATT, B. M. (1994). Explaining the Formation of International New Ventures. Journal of Business Venturing, 9, p.469-487.

[37] OVIATT, B. M.; McDOUGALL, P. P. (1994). Toward a Theory of International New Ventures. Journal of International Business Studies, 24, pp. 45-64.

[38] OVIATT, B.M., McDOUGALL, P.P. (1997). Challenges for internationalization process theory: the case of international new ventures. Management International Review, V. 37, N. 2, pp. 85-99.

[39] OVIATT, B. M.; McDOUGALL, P.P. (1995). Global Starts-Ups: Entrepreneurs on a Worldwide Stage. The Academy of Management Executive, 9, p.30-44.

[40] PICCHIAI, D.; ZORZETTI, J.C. (2018). Internacionalização de empresas nascentes. Conhecimento Interativo, São José dos Pinhais, PR, v.12, n.1, p.168-202.

[41] RIALP, A.; RIALP, J.; KNIGHT, G. (2005). The phenomenon of early internationalizing firms: what do we know after a decade (1993-2003) of scientific inquiry? International Business Review, v.8, n.14, p.147-66. 
[42] RIBEIRO, F. C. F. (2012). Born Globals brasileiras: estudo da internacionalização de empresas de base tecnológica. Tese de doutorado. FEA USP, Universidade de São Paulo.

[43] RIBEIRO, F. C. F.; PIMENTEL, J. A. (2009). Empresas born globals brasileiras: an influência do perfil do empreendedor e da localização geográfica. 33 Encontro Anpad, São Paulo, Brasil,

[44] ROBERTS, E.; SENTURIA, T. (1996). Globalizing the emerging light-technology company: Industrial Marketing Management, 25, p.491-506.

[45] ROCHA, A. (2004). O construto da distância psicológica: componentes, mediadores e assimetria. In: HEMAIS, Carlos A. (Org.). 0 desafio dos mercados externos: teoria e prática na internacionalização da firma. V. 1. Rio de Janeiro: Mauad.

[46] ROCHA, A.; et al. (2007) Expansão internacional das empresas brasileiras: revisão e síntese. In: Fleury, A; Fleury, M. T. (Ed.). Internacionalização e os países emergentes. São Paulo: Atlas.

[47] RENNIE, M. (1993). Born Global. McKinsey Quarterly, 4, p.25-52.

[48] SHARMA, D., BLOMSTERMO, A. (2003). The internationalization process of Born Globals: a network view. International Business Review, 12, p.739-753.

[49] SILVA, R. C. M.; CHAUVEL, M. A.; BERTRAND, H. (2010). Internacionalização de pequenas empresas: um estudo de caso com uma empresa brasileira de tecnologia. Gestão \& Regionalidade, v.26, n.76, p.43-62

[50] SILVA, R. S.; DIB, L. A. (2011). Processos de Internacionalização de Born Globals: Estudo de Casos de Empresas Brasileiras de Software. V Encontro Estratégia da ANPAD, Porto Alegre.

[51] SOUZA, E.; LIMA, A. (2016). Born Globals: uma revisão da teoria e sugestões para iniciativas de

[52] pesquisa no Brasil. XIX Seminários em Administração. São Paulo: Universidade de São Paulo.

[53] VERNON, R. (1966). International investment and international trade in the product cycle. Quarterly Journal of Economics, v. 80, p. 190-207.

[54] VERNON, R. (1979). The product cycle hypothesis in a new international environment. Oxford Bulletin of Economics and Statistics, v. 42, n. 4, p.255-67.

[55] WENNBERG, K., HOLMQUIST, C. (2008). Problemistic search and international entrepreneurship. European Management Journal, 26, p.441-454.

[56] WILLIAMSON, O. (1975). Markets and Hierarchies: Analysis and Antitrust Implications. New York: Free Press.

[57] ZUCHELLA, A. (2002). Born Global versus gradually internationalizing firms: an analysis based on the Italian case. XXVIII EIBA Conference. Athens. 